\title{
GCU
}

Glasgow Caledonian

University

University for the Common Good

\section{Mössbauer and XRD study of novel quaternary Sn-Fe-Co-Ni electroplated alloy}

Kuzmann, E.; Sziráki, L.; Stichleutner, S.; Homonnay, Z.; Lak, G. B.; El-Sharif, M.; Chisholm, C.U.

\section{Published in:}

Hyperfine Interactions

DOI:

10.1007/s10751-017-1474-y

Publication date:

2017

Document Version

Author accepted manuscript

Link to publication in ResearchOnline

Citation for published version (Harvard):

Kuzmann, E, Sziráki, L, Stichleutner, S, Homonnay, Z, Lak, GB, El-Sharif, M \& Chisholm, CU 2017, 'Mössbauer and XRD study of novel quaternary Sn-Fe-Co-Ni electroplated alloy', Hyperfine Interactions, vol. 238, 97. https://doi.org/10.1007/s10751-017-1474-y

\section{General rights}

Copyright and moral rights for the publications made accessible in the public portal are retained by the authors and/or other copyright owners and it is a condition of accessing publications that users recognise and abide by the legal requirements associated with these rights.

Take down policy

If you believe that this document breaches copyright please view our takedown policy at https://edshare.gcu.ac.uk/id/eprint/5179 for details of how to contact us. 


\title{
Mössbauer and XRD study of novel quaternary Sn- Fe-Co-Ni electroplated alloy
}

\author{
E. Kuzmann ${ }^{1}$, L. Sziráki ${ }^{1}$, S. Stichleutner ${ }^{2}$, Z. Homonnay ${ }^{1}$, Gy. Lak ${ }^{3}$, M. El-Sharif ${ }^{3}$, \\ C.U. Chisholm ${ }^{3}$ \\ ${ }^{1}$ Institute of Chemistry, Eötvös Loránd University, Budapest, Hungary \\ ${ }^{2}$ Nuclear Analysis Department, Centre for Energy Research, HAS, Budapest, Hungary \\ ${ }^{3}$ Glasgow Caledonian University, Glasgow, Scotland, U.K. \\ e-mail of the corresponding author: kuzmann@caesar.elte.hu
}

\begin{abstract}
A constant current technique electrochemical deposition was used to obtain quaternary alloys of Sn Fe-Co-Ni, which to date have not been reported in the literature, from a gluconate electrolyte. For the characterization of electroplated alloys ${ }^{57} \mathrm{Fe}$ and ${ }^{119} \mathrm{Sn}$ conversion electron Mössbauer spectroscopy (CEMS) and XRD were used. XRD revealed the amorphous character of the novel Sn-Fe-Co-Ni electrodeposited alloys. ${ }^{57} \mathrm{Fe}$ Mössbauer spectrum of quaternary deposit displayed a magnetically split sextet with broad lines typical of iron bearing ferromagnetic amorphous alloys. Magnetically split ${ }^{119} \mathrm{Sn}$ spectra reflecting a transferred hyperfine field were also observed. New quaternary Sn-FeCo-Ni alloys were successfully prepared.
\end{abstract}

\section{Keywords}

${ }^{57} \mathrm{Fe}$ and ${ }^{119} \mathrm{Sn}$ Mössbauer spectroscopy, CEMS, XRD, electrodeposition, quaternary Sn-Fe-Co-Ni alloy

\section{Introduction}

Electrodeposited tin-based alloys with nanometer based structures are viewed as important electrode materials. They may have potentially important applications for energy efficient cells, as materials for high performance electrodes in lithium cells and as environmentally acceptable corrosion resistant materials. Electrodeposition processes have the potential to facilitate the deposition of such tin-based alloys which are non-existent in the 
thermal equilibrium diagram and cannot be prepared by thermal methods. In order to find suitable conditions for electrodeposition to achieve multicomponent alloy deposits without segregation of equilibrium binary phases was the fundamental basis for this research study. ${ }^{57} \mathrm{Fe}$ and ${ }^{119} \mathrm{Sn}$ conversion electron Mössbauer spectroscopy (CEMS), and X-ray diffraction (XRD) proved to be excellent tools to characterize the electrodeposited alloy coatings [1-3]. In the present work novel Sn-Fe-Co-Ni alloy coatings were deposited by constant current method on copper substrates from an aqueous gluconate based electrolyte.

\section{Experimental}

The coatings were deposited in a cell of two electrode system onto $\mathrm{Cu}$ substrate using galvanostatic mode. The basis of the electrolyte is given in Table 1.

Table 1. The basis of electrolyte.

\begin{tabular}{|c|c|}
\hline Sodium gluconate & $0.3 \mathrm{~mol} \mathrm{dm}^{-3}$ \\
\hline Peptone & $0.1 \mathrm{~g} \mathrm{dm}^{-3}$ \\
\hline $\mathrm{Sn} \mathrm{SO} 4$ & $0.03 \mathrm{~mol} \mathrm{dm}^{-3}$ \\
\hline $\mathrm{Fe} \mathrm{SO}_{4}$ & $0.02 \mathrm{~mol} \mathrm{dm}^{-3}$ \\
\hline $\mathrm{Co} \mathrm{SO}_{4}$ & $0.01 \mathrm{~mol} \mathrm{dm}^{-3}$ \\
\hline $\mathrm{Ni} \mathrm{SO}_{4}$ & $0.05 \mathrm{~mol} \mathrm{dm}^{-3}$ \\
\hline Ascorbic acid & $0.01 \mathrm{~mol} \mathrm{dm}^{-3}$ \\
\hline
\end{tabular}

Deposition was performed at a temperature of $22{ }^{\circ} \mathrm{C}$, using a $\mathrm{pH}$ of 5.1 and plating times of 15-30 min.

The ${ }^{57} \mathrm{Fe}$ and 119Sn conversion electron Mössbauer measurements of electrodeposited alloy coatings were carried out with a conventional constant acceleration (WISSEL) 
Mössbauer spectrometer using integrated multichannel analyzer and RANGER type CEM detector in reflection geometry at room temperature. ${ }^{57}$ Co source of $0.8 \mathrm{GBq}$ activity in $\mathrm{Rh}$ matrix and a $9 \mathrm{mCi}$ activity $\mathrm{Ca}^{119 m} \mathrm{SnO}_{3}$ source supplied the gamma rays. The isomer shift values are given relative to $\alpha$-iron at room temperature for ${ }^{57} \mathrm{Fe}$ spectra and to $\mathrm{CaSnO}_{3}$ for ${ }^{119}$ Sn spectra. The analysis of the Mössbauer spectra was carried out with the MOSSWINN 4.0 code [4].

The powder X-ray diffractograms of the samples were measured in Bragg-Brentano geometry using a DRON-2 computer controlled diffractometer (at $45 \mathrm{kV}$ and $35 \mathrm{~mA}$ ) with $\beta$ filtered $\mathrm{FeK}_{\alpha}$ radiation ( $\lambda=0.193735 \mathrm{~nm}$ ) at room temperature. In certain cases the appearance of small intensity $\mathrm{K}_{\beta}$ peaks could not be avoided. The goniometer speed chosen was $1 / 4{ }^{\circ} \mathrm{min}^{-1}$ in the range of $2 \Theta=20-100^{\circ}$. The diffraction patterns were evaluated using EXRAY peak searching software (developed by Z. Klencsár at the Eötvös University, 1996). The details of these results will be published elsewhere.

\section{Results and discussion}

The polarisation curve depicted in Fig. 1 shows that to deposit amorphous quaternary alloys high nucleation overvoltage should be achieved along with inhibition of crystal growth. SEM micrograph (Fig. 2) reflects homogeneous, uniform and bright Sn-Fe-Co-Ni coatings that were successfully produced from a gluconate and peptone containing electrolyte. The details of electrochemical and microscopy measurements will be published elsewhere. 


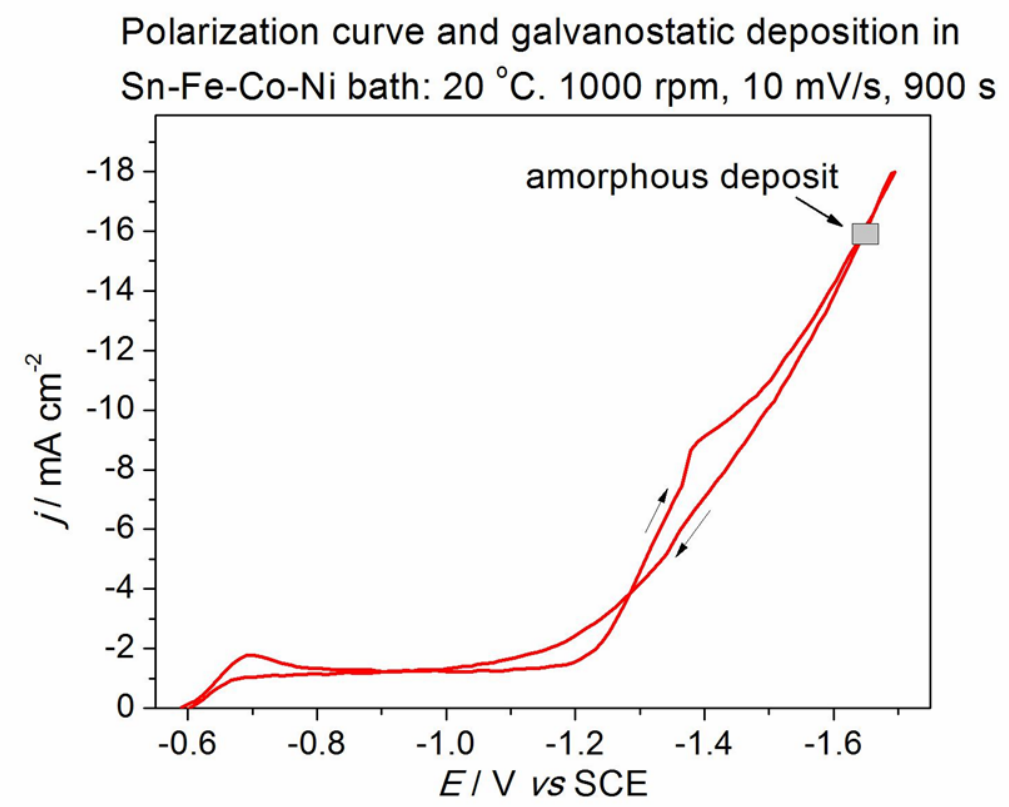

Figure 1. Polarisation curve and galvanostatic deposition of Sn-Fe-Co-Ni alloy.

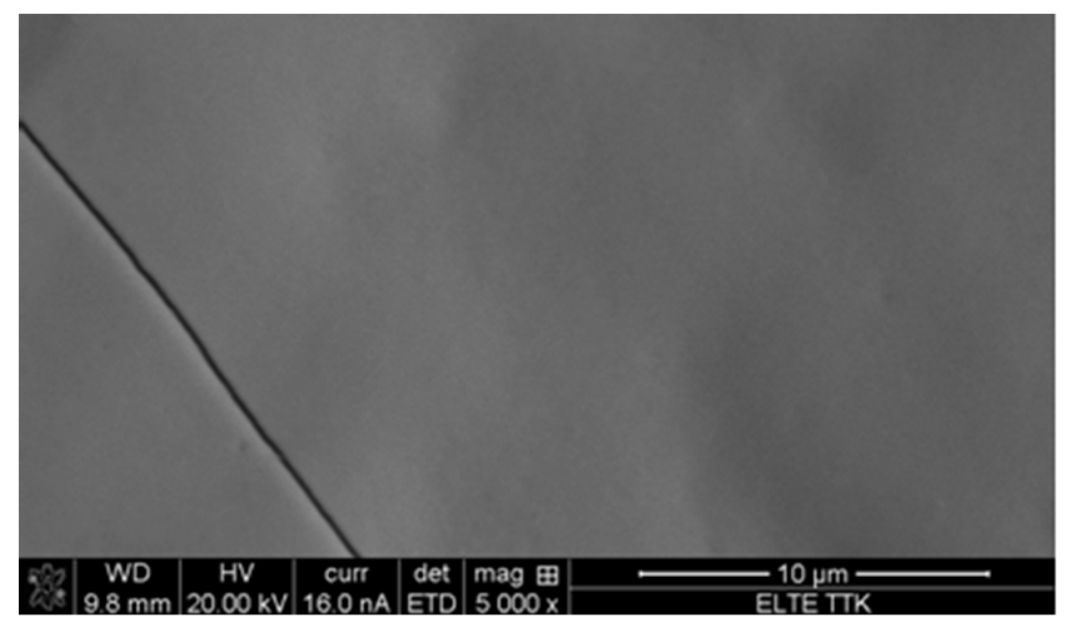

Figure 2. SEM micrograph of an electrodeposited Sn-Fe-Co-Ni alloy

The XRD pattern of a quaternary Sn-Fe-Co-Ni alloy deposit is shown in Fig. 3. 


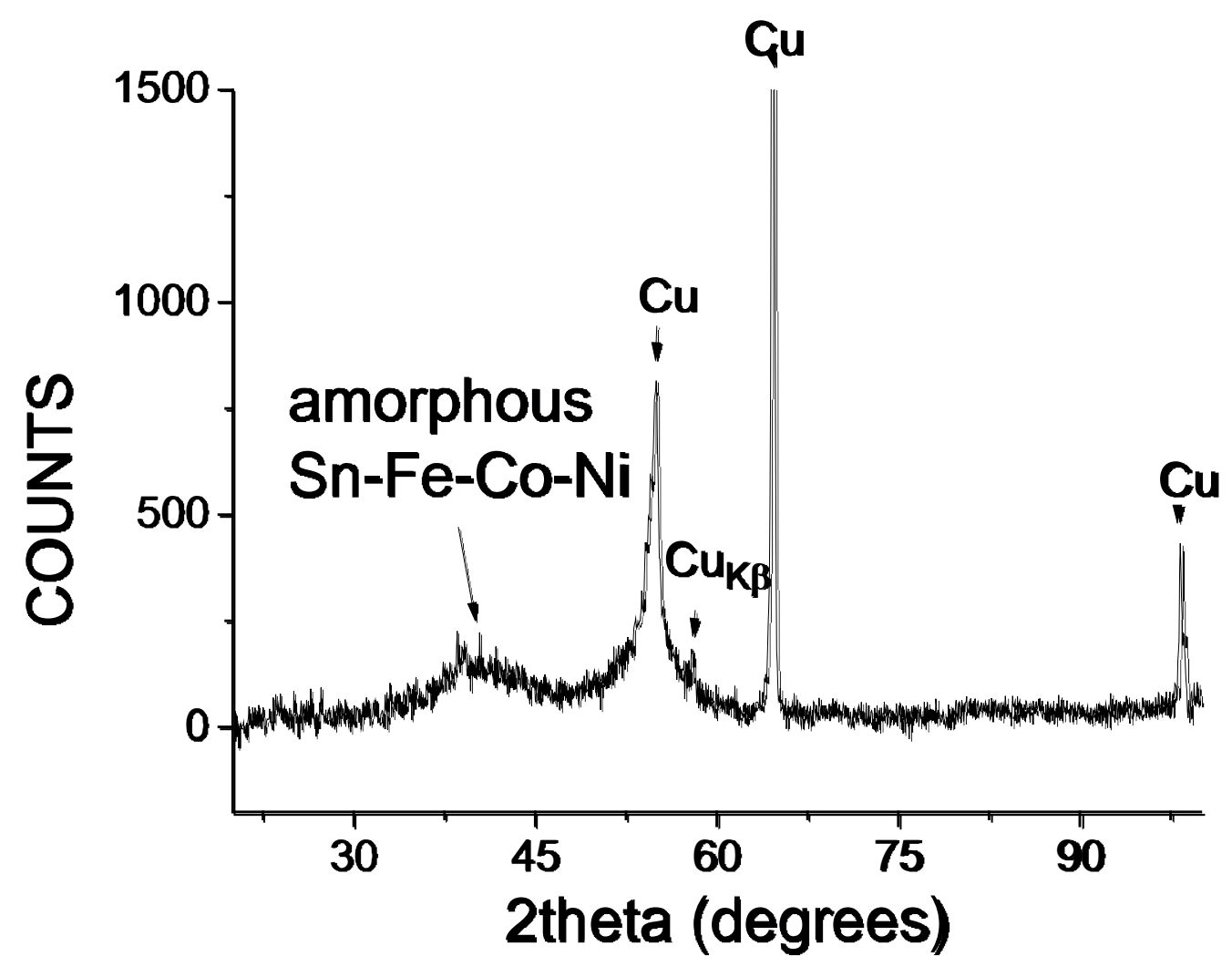

Figure 3. XRD pattern of electrodeposited Sn-Fe-Co-Ni alloy

Except the lines belonging to the $\mathrm{Cu}$ substrate, the lines are very broad reflecting an amorphous main phase in the diffractogram of the electrodeposited Sn-Fe-Co-Ni alloy. The highest intensity peaks and also a $\mathrm{K}_{\beta}$ line originate from the reflections of the $\mathrm{Cu}$ substrate, since the penetration depth of the X-ray $(\sim 25 \mu \mathrm{m})$ is much higher than the thickness of the deposit. Since no sharp lines, besides those belonging to $\mathrm{Cu}$ substrate, can be observed in the diffractograms, XRD reveals the existence of a new metastable amorphous alloy phase.

The ${ }^{57} \mathrm{Fe}$ and ${ }^{119} \mathrm{Sn}$ conversion electron Mössbauer spectra of a quaternary Sn-Fe-Co-Ni sample are shown in Fig. 4 and Fig. 5, respectively. 


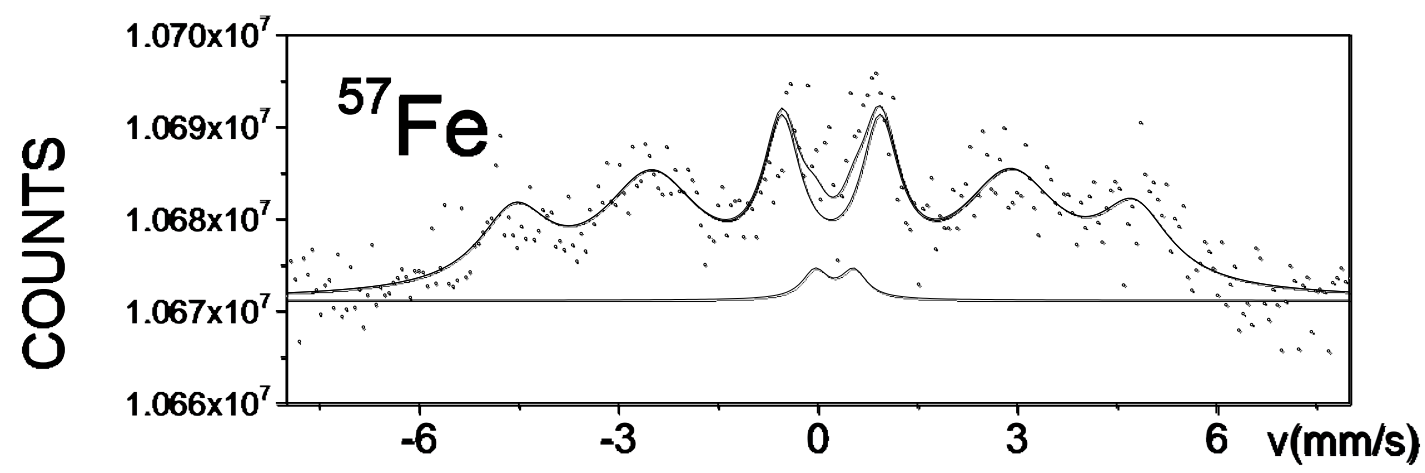

Figure 4. ${ }^{57} \mathrm{Fe}$ CEM spectrum of electrodeposited Sn-Fe-Co-Ni alloy

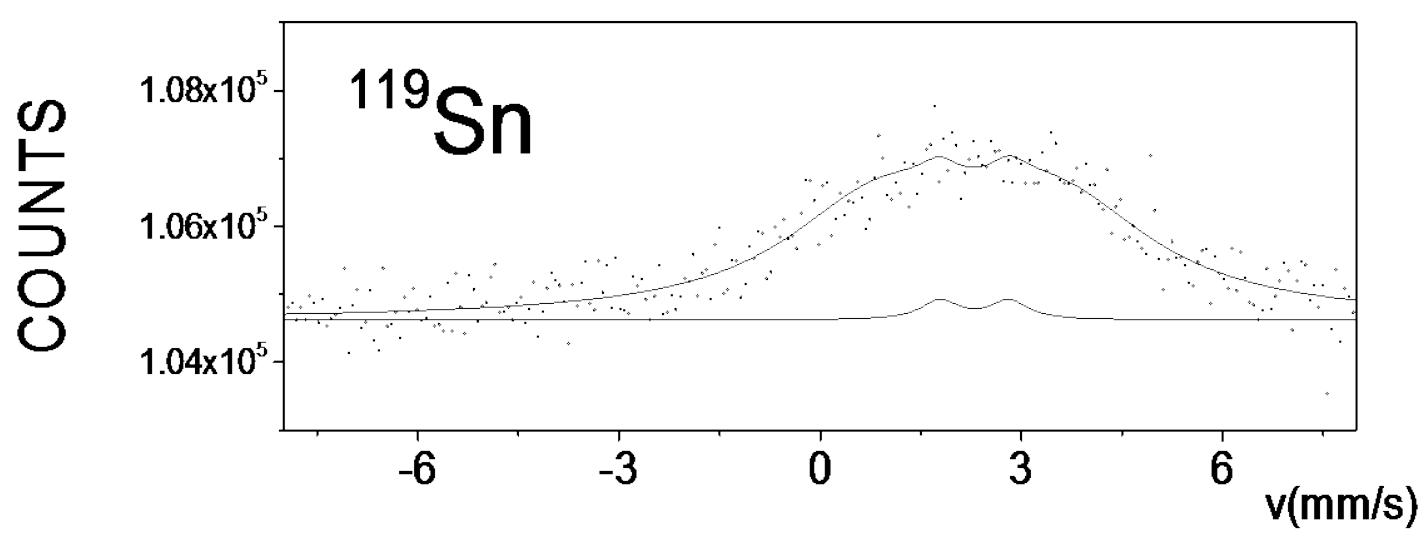

Figure 5. ${ }^{119}$ Sn CEM spectrum of electrodeposited Sn-Fe-Co-Ni alloy

The ${ }^{57}$ Fe Mössbauer spectrum of quaternary deposit (Fig. 4) displays a magnetically split sextet with broad lines typical of iron bearing amorphous alloys. The envelope of the broad sextet can be considered as a superposition of a large number of magnetically split subspectra belonging to iron atoms in slightly different microenvironments within the amorphous alloy phase. Thus the ${ }^{57} \mathrm{Fe}$ Mössbauer spectrum reveals the fully amorphous state of the quaternary deposit in accordance with its XRD result. The Mössbauer spectrum was decomposed into a dominant sextet with broad lines and a minor doublet similarly as was performed with the ternary alloys [1-3]. The average Mössbauer parameters are given in Table 2. The 
corresponding hyperfine field distribution is shown in Fig. 6. The sextet is assigned to ferromagnetic Sn-Fe-Co-Ni alloy phase, while the doublet is assigned to paramagnetic SnFe-Co-Ni alloy phase, in accordance with the cases of the ternary Sn-Co-Fe and Sn-Ni-Fe alloys [1-3]. The ferromagnetic phase is the dominant one.

Table 2. Average Mössbauer parameters of ${ }^{57}$ Fe CEM spectrum of -quaternary Sn--Fe-Co-Ni alloy.

\begin{tabular}{|l|l|}
\hline SEXTET* & \\
\hline$A(\%)$ & 96.9 \\
\hline$\delta(\mathrm{mm} / \mathrm{s})$ & $0.15 \pm 0.02$ \\
\hline$B(\mathrm{~T})$ & $28.91 \pm 0.12$ \\
\hline DOUBLET & \\
\hline$A(\%)$ & 3.1 \\
\hline$\delta(\mathrm{mm} / \mathrm{s})$ & $0.24 \pm 0.02$ \\
\hline$\Delta(\mathrm{mm} / \mathrm{s})$ & $0.60 \pm 0.04$ \\
\hline
\end{tabular}

* evaluated as hyperfine field distribution

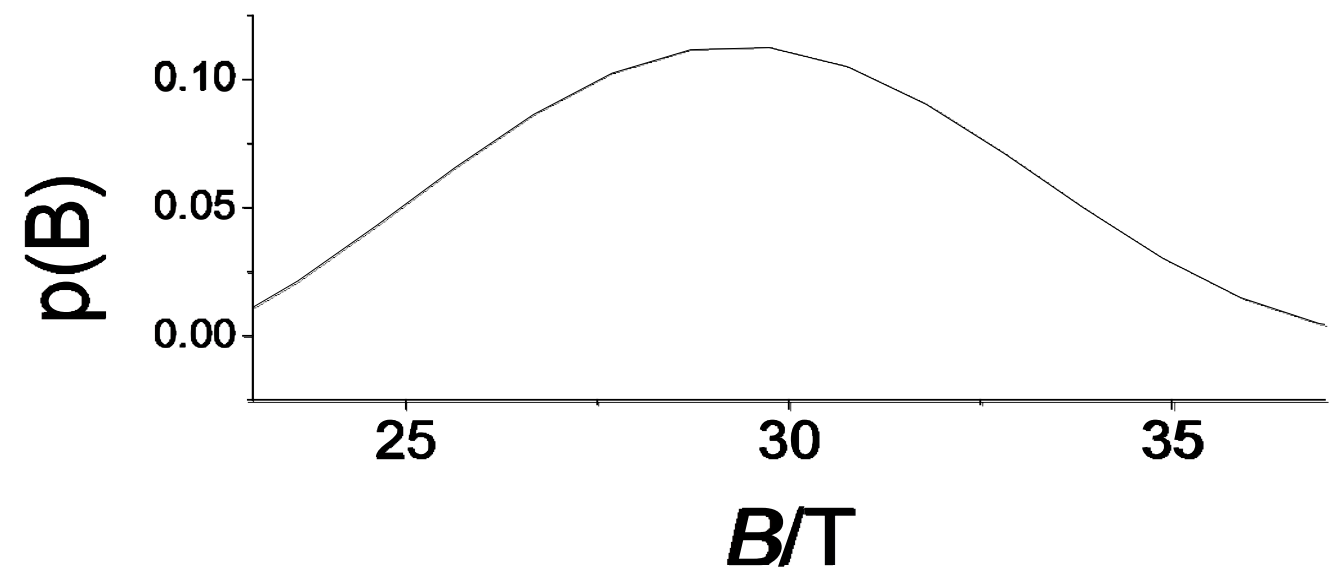

Figure 65 . Hyperfine field distribution derived from the ${ }^{57} \mathrm{Fe}$ CEM spectrum of electrodeposited SnFe-Co-Ni quaternary alloy. 
The ${ }^{57}$ Fe hyperfine field distribution of quaternary Sn-Fe-Co-Ni electrodeposits derived from the Mössbauer spectrum was in a fairly good agreement with that calculated based upon the alloying effect on the quaternary system supposing random distribution of the constituting element. The average hyperfine field value can also be explained by supposing randomly distributed $\mathrm{Sn}-\mathrm{Fe}-\mathrm{Co}-\mathrm{Ni}$ alloy phase. e.g. for the average ${ }^{57} \mathrm{Fe}$ hyperfine field obtained $\mathrm{B}_{\mathrm{Fe}}=$ $28.9 \mathrm{~T}$ for $37.0 \mathrm{wt} \%$ Sn, $16.8 \mathrm{wt} \%$ Co and $7.4 \mathrm{wt} \% \mathrm{Ni}$ when the multinomial distribution gives maximum values of $\mathrm{n}_{\mathrm{Sn}}=4, \quad \mathrm{n}_{\mathrm{Co}}=3$ and $\mathrm{n}_{\mathrm{Ni}}=2$, where $\mathrm{n}_{\mathrm{Sn}}$ and $\mathrm{n}_{\mathrm{Co}}$ for the number of sites occupied by the Sn and $\mathrm{Co}$, and $\mathrm{Ni}$, respectively, in first the coordination sphere. By substituting these values into the formula of hyperfine field $B=B o+\mathrm{n}_{\mathrm{Sn}} \Delta B_{\mathrm{Sn}}+\mathrm{n}_{\mathrm{Co}} \Delta B_{\mathrm{Co}}+\mathrm{n}_{\mathrm{Ni}} \Delta B_{\mathrm{Ni}}$ using $\Delta B_{\mathrm{Sn}}=-2.3 \mathrm{~T}, \Delta B_{\mathrm{Co}}=1.1 \mathrm{~T}$ and $\Delta \mathrm{B}_{\mathrm{Ni}}=0.9 \mathrm{~T}$ values for the hyperfine field decrements, which values are consistent with those found for the corresponding ternary alloys [5] we obtained a resonant agreement with the field (28.9 T) as was observed in the spectrum. This may suggest a model for the structure of the amorphous Sn-Fe-Co-Ni deposit where the atoms in the short range structure would be randomly distributed somewhat similarly to the solid solution phase of the quaternary alloys.

The ${ }^{119}$ Sn Mössbauer spectrum (Fig. 5) also shows magnetically split envelope with broad lines. The magnetic splitting is due to a transferred hyperfine field originated from the neighboring magnetic atoms. The spectrum can be considered to be composed from a large number of subspectra with different hyperfine fields which can correspond well to the number of various microenvironments of $\mathrm{Sn}$ in the amorphous Sn-Fe-Co-Ni alloy. The ${ }^{119} \mathrm{Sn}$ Mössbauer spectrum (Fig. 5) can be decomposed into a dominant sextet and a minor doublet, which parameters are shown in Table 3. 
Table 3. Mössbauer parameters of ${ }^{119}$ Sn CEM spectrum of quaternary Sn-Fe-Co-Ni alloy.

\begin{tabular}{|l|l|}
\hline SEXTET* & \\
\hline$A(\%)$ & 96.6 \\
\hline$\delta(\mathrm{mm} / \mathrm{s})$ & $2.11 \pm 0.04$ \\
\hline$B(\mathrm{~T})$ & $2.31 \pm 0.12$ \\
\hline DOUBLET & \\
\hline$A(\%)$ & 3.4 \\
\hline$\delta(\mathrm{mm} / \mathrm{s})$ & $2.20 \pm 0.03$ \\
\hline$\Delta(\mathrm{mm} / \mathrm{s})$ & $1.03 \pm 0.05$ \\
\hline
\end{tabular}

* evaluated as hyperfine field distribution

The ${ }^{119}$ Sn Mössbauer results are consistent with the occurrence of a dominant ferromagnetic and a minor paramagnetic amorphous $\mathrm{Sn}-\mathrm{Fe}-\mathrm{Co}-\mathrm{Ni}$ phase as was shown by the ${ }^{57} \mathrm{Fe}$ Mössbauer and XRD results, similarly as in the cases of the ternary alloys [1-3].

\section{Conclusions}

We have succeeded in finding electrodeposition preparation conditions at which the formation of ferromagnetic amorphous Sn-Fe-Co-Ni quaternary alloy could be observed.

XRD and Mössbauer results confirmed the existence of a new metastable amorphous ferromagnetic Sn-Fe-Co-Ni alloy phase within the quaternary alloy deposits.

The amorphous alloy phase was found to be the dominant phase for the $\mathrm{Sn}-\mathrm{Fe}-\mathrm{Co}-\mathrm{Ni}$ electrodeposits investigated.

The characteristics of the novel Sn-Fe-Co-Ni quaternary alloy and the features of electrodeposition are similar to those of ternary Sn-Co-Fe and Sn-Ni-Fe alloys, where 
adherent, bright, uniform amorphous alloy coatings are formed without containing other (equilibrium binary) phases of the constituents.

\section{Acknowledgements}

The financial supports from the NKFIH-OTKA (No K115913 and K115784) as well as Hungarian-Croatian S\&T (No TÉT_16-1-2016-0002) grants are acknowledged.

\section{References}

[1] C.U. Chisholm, E. Kuzmann, M. El-Sharif, O. Doyle, S. Stichleutner, K. Solymos, Z. Homonnay, A. Vértes, Appl. Surf. Sci. 253, 4348 (2007).

[2] L. Sziráki, E. Kuzmann, M. El-Sharif, C.U. Chisholm, S. Stichleutner, G.B. Lak, K. Süvegh, E. Tatár, Z. Homonnay, A. Vértes, Appl. Surf. Sci. 256, 7713 (2010).

[3] L. Sziráki, E. Kuzmann, G.B. Lak, M. El-Sharif, C.U. Chisholm, S. Stichleutner, K. Havancsák, , K. Zih-Perényi, Z. Homonnay, A. Vértes, Surf. Coat. Tech. 211, 184 (2012). [4] Z.Klencsár, E. Kuzmann, A. Vértes, J. Radioanal. Nucl. Chem. 210, 105-118 (1996)

[5] E. Kuzmann, L. Sziráki, G. B. Lak, S. Stichleutner, K. Havancsák, K. Süvegh, M. ElSharif, C.U. Chisholm, A. Vértes, AIP Conf. Proc. 1489, 3-12 (2012) 